Article

\title{
Ownership structures and firm performance in Nigeria: A canonical correlation analysis
}

\author{
Abdul Adamu ${ }^{*}$ and Joel Haruna ${ }^{2}$ \\ 1 Nasarawa State University, Keffi-Nigeria; adamuabdulmumeen@nsuk.edu.ng \\ 2 Access Bank Plc. Abuja - Nigeria; joelharry2004@yahoo.co.uk \\ * Correspondence: adamuabdulmumeen@nsuk.edu.ng; Tel.: +2348064851648
}

Received: 18 May 2020; Accepted: 20 July 2020; Published: 22 July 2020

\begin{abstract}
This study examined the relationship between ownership structure and performance of listed non-financial firms in Nigeria. Secondary data on managerial ownership, ownership concentration, foreign ownership, institutional ownership, Tobin q, return on assets, return on equities, and earnings per shares were collected from forty (40) sampled firms. The data were analyzed using canonical correlation and the findings showed that managerial and foreign ownerships are the dominant ownership structures while Tobin q, EPS, and ROA are the dominant performance measures. The study also found that ownership concentration, foreign ownership, and institutional ownership are positively correlated with firm performance, while managerial ownership is negatively correlated with firm performance. The study recommended that listed non-financial firms should encourage foreign investments in their firms and rewards performing managers with shares in the firm.
\end{abstract}

Keywords: Ownership structure; Performance; Multivariate data; and Canonical Correlation

JEL codes: G32; C390.

\section{Introduction}

One of the primary corporate governance mechanisms is ownership structure and that is why the relationship between ownership structure and firm performance has been an important subject and ongoing debate in the corporate finance literature. The fundamental insight into this debate dates back to Berle and Means (1932), who argued that the separation of ownership and control of modern corporations naturally reduces management incentives to maximize corporate efficiency. Their concerns were later developed by Jensen and Meckling (1976) into what has subsequently become the "agency theory", which has been characterized as "a theory of the corporate ownership structure" and the guiding framework for ownership-performance studies. Privy to this, in a related study by Demsetz and Lehn (1985), they stated that the ownership structure concept indicates that ownership is often endogenously determined for the maximization of the performance of the company as this benefits all owners.

Since these early insights into this relationship, it has been extensively examined by analysts as well as scholars throughout the years. The modern organization emphasizes the divorce of management and ownership; in practice, the interests of group managing the company can differ from the interests of those that supply the capital to the firm. The concentration of ownership is considered as the tool for aligning the CEO self-intrinsic behavior to reduce the agency conflict and achieve the value maximization objective of the firms.

Shareholders of publicly held corporations are so numerous and small that they are unable to effectively control the decisions of the management team, and thus cannot be assured that the 
management team represents their interests. Many solutions to this problem have been advanced, like the disciplining effect of the takeover market, the positive incentive effects of the management shareholding stake, and the benefits of large monitoring shareholders. A different problem, however, arises in firms with large controlling shareholders. Since a large controlling shareholder has both the incentives and the power to control the management team's actions, management's misbehavior is a second-order problem when such a large shareholder exists. Instead, the main problem becomes controlling the large shareholder's abuse of minority shareholders. In other words, holders of a majority of the voting shares in a corporation, through their ability to elect and control a majority of the directors and to determine the outcome of shareholders' votes on other matters, have tremendous power to benefit themselves at the expense of minority shareholders. Thus, the type of owners as well as the distribution of ownership stakes will undoubtedly have an impact on the performance of firms.

Most of the empirical literature studying the link between ownership structure and firm performance usually provide different and conflicting evidence on the effects. There are different reasons for these disagreements. It may be a result of researchers applying different estimation methods, performance and ownership measures, samples, and the corporate governance environment in which the firm operates.

This paper is a moderate attempt to examine this relationship in Nigeria using a different estimation method, the canonical correlation. Ownership structure as the independent variable has multiple proxies that measure it, the same applies to firm performance as the dependent variable. This is the reason why most empirical researches in this area apply different variants of multiple regression, which can only use a single proxy as a dependent variable at a time. But for this research problem, however, the researcher is interested in relationships between sets of multiple dependent and multiple independent variables. Thus, the Canonical correlation analysis is the answer as it is a method that enables the assessment of the relationship between two sets of multiple variables. The data for the study is from five years financial statements of 40 non-financial firms between 2011 and 2015.the ratios used were four each for ownership structure and firm performance. The findings showed that ownership structure variables are positively correlated with firm performance.

This study is divided into five sections. This first section is the introduction, which contains the motivation of the study and its objective. The second section is the literature review, which looked at the various studies in this area. The third section is data and methods, where the data used for the study were described. The fourth section is where we present the results and discuss the implications of the results. The final section concludes the study by summarizing the findings of the study.

\section{Literature Review}

There are several studies on ownership structure and firms' performance in both developing and developed countries (See Table 1 for a description of some of these studies). These studies, the differences in their locations, methodologies, and sectors made their findings differ. While some report significant effects of ownership structure on the performance of firms, others report insignificant effects of ownership structure on firms' performance. These divergent findings may also be a result of differences in the choice of variables used for ownership structure and also those of firms' performance.

Rashid (2020) examined the mediating role of corporate board characteristics in the relationship between ownership structure and firm performance in the listed public limited companies of Bangladesh. The study found that foreign ownership and director ownership have a significant positive influence on both accounting and market-based firm's performance, while institutional ownership exhibits positive influence only on return on assets. The mediating effect results show that board size and board independence partially mediate the relationship between ownership structure and firm performance. Similarly, Al Farooque et al. (2020) investigated the effects of the corporate board, audit committee characteristics, and ownership structures on the market-based financial performance of listed firms in Thailand. Using GMM (generalized method of moments) and ordinary least squares on a sample of 452 firms, it was found that ownership concentration and family 
ownership have no significant influence on market-based firm performance, while managerial ownership exerts a positive effect on performance. The study of Kao et al. (2018) used the data set of listed firms in Taiwan to empirically assess the effects of ownership structure and board of directors on firm value. The study employed panel estimation and 2SLS and found that block-holders' ownership, institutional ownership, foreign ownership, and family ownership are all positively related to firm value.

Other studies are Alabdullah (2018); Mardnly et al. (2018); Ali et al. (2018). Alabdullah (2018) studied the link between ownership structure and firm performance in Jordan employing the multiple regression method to analyze data for non-financial firms listed in the Amman Stock Exchange. The study found managerial ownership has a positive impact on performance, showed no evidence to support the impact of foreign ownership on performance. Mardnly et al. (2018) examined the impact of aggregate and individual corporate governance provisions on firm performance on all firms listed at Damascus Securities Exchange (DSE). The study used multiple linear regression models and found that ownership structure is the only significant corporate governance provision in determining Syrian firms' performance, as it loads positively and significantly on firm performance proxies (ROA and EPS). The analysis of ownership structure items showed that foreign ownership has a positive and significant impact on performance. While Ali et al. (2018) analyzed the impact of ownership structure on firm performance and valuation across different geographical regions within mainland China using multivariate regression technique and found that institutional and state ownerships negatively affect market valuation throughout various geographical regions of China. Further, in East, Northwest, South Central, and Southwestern parts of China, managerial ownership and concentration of shareholding among the top 10 shareholders positively influence Return on Equity (ROE). Interestingly, institutional shareholding negatively affects Return on Assets (ROA), while institutional ownership has a neutral effect on the profitability margin in Northeast China. Although in the Northern part of China, this relationship is slightly positive. In the East China region, state ownership and ownership concentration are directly proportional to profitability margin.

Al-Matari and Al-Arussi (2016) investigated the effect of ownership structure characteristics on firm performance in Oman. The study measured ownership structure using ownership concentration, managerial ownership, and government ownership and firm performance using the return on assets (ROA). Using multiple regression analysis on a sample of 81 firms for the period between 2012 and 2014, the study found a positive and significant association between ownership concentration, government ownership, and firm performance. Tahir, Saleem, and Arshad (2015) explore the relationship between institutional ownership and firm performance in Pakistan between 2008and 2013. The study reported the issue of endogeneity problem and to deal with it, OLS and 2SLS were used. It was found that institutional ownership has a significant and positive relationship with firm performance. Firm performance was found to be negatively related to debt ratio and fixed expenditures.

Srivastava (2011) investigated whether ownership type affects some key accounting and market performance indicators of listed firms in India and found the presence of highly concentrated ownership structure in the Indian market. The study used the regression and concludes that the dispersed ownership percentage influences certain dimensions of accounting performance indicators (ROA and ROE) but not stock market performance (P/E and P/BV). Similar to Srivastava (2010), Jadoon and Bajuri (2015) looked at the performance measure of firms in Pakistan from both accounting and market-based perspective but used Tobin Q. The study measured ownership concentration using the percentage of shareholding by the largest shareholder, five largest shareholders, and ten largest shareholders. Employing multiple regression, it was found that ownership concentration has a positive impact on firm performance for both accounting and market base performance parameters. However, Manawaduge and De Zoysa (2013) in Sri Lanka found that a greater concentration of ownership leads to better performance, using accounting measures, but found no significant impact using market-based performance measures. Also similar to Jadoon and Bajuri (2015), on a study of listed companies in Iran, Alipour and Amjadi (2011) found that the effect is significant and negative 
for ownership of biggest shareholder, positive and significant for ownership of five greater shareholders. It is also significant and negative for the institutional shareholders, managerial shareholding, and individual shareholders. In the studies of Srivastava (2011), and Jadoon and Bajuri (2015), both the dependent and independent variable has more than one variable which shows contradicting results.

Measuring ownership structure using institutional and block ownership in a study of manufacturing companies in Sri Lanka, Abeyrathna, and Ishari (2016) found that while block ownership has a negative and insignificant relationship with firm performance, institutional ownership has a positive and insignificant relationship with firm performance. This finding is consistent with that of Demsetz and Villalonga (2001). The proxies used for ownership structure in Israel by Lauterbach and Vanisky's (1999) study were family firms, firms controlled by partnerships of individuals, concern-controlled firms, and firms where block holders have less than $50 \%$ of the vote. The study employed the technique of Data Envelopment Analysis and found that owner-manager firms are less efficient in generating net income than firms managed by a professional (non-owner) manager and that family firms run by their owners perform (relatively) the worst. This evidence suggests that the modern form of business organization, namely the open corporation with dispersed ownership and non-owner managers, promotes firm performance.

Using pooled data, Manawaduge and De Zoysa (2013) measured performance with accounting and market-based indicators and provided evidence for a strong positive relationship between ownership concentration and accounting performance measures. However, the study found no significant impact on using market-based performance measures. Looking at variables of ownership from whether the firm is majorly owned or minority-owned by foreigners, Gurbuz and American (2010) employed panel analysis on a company listed on the Istanbul Stock Exchange and found that minority foreign-owned companies (MIN) perform better than domestic ones (DOM) in terms of operating profitability. When the return on assets is employed as a performance measure, it is observed that MIN performs better than both DOM and majority foreign-owned companies (MAJ). It is also found that MAJ performs worse than DOM. Their overall conclusion was that foreign ownership improves firm financial performance in Turkey up to a certain level, beyond which additional ownership by the foreigners does not add to firm profitability.

Focusing on the conflict between majority and minority shareholders, and differentiating between the behavior of family and nonfamily firms using 586 non-listed Spanish firms, Arosa et al. (2009) found that a greater concentration of firm owners in the first generation of businesses may bring the monitoring and expropriation hypotheses into play, whereas firms in which subsequent generations have joined may show a greater spread of ownership. In first-generation family firms, the classic owner-manager conflict is mitigated due to the large shareholder's greater incentives to monitor the manager (Arosa et al, 2009). However, the second type of conflict appears. The large shareholder may use its controlling position in the firm to extract private benefits at the expense of the small shareholders. Scholten (2014) measured quadratic effects of ownership concentration (total and insider) on firm performance and found that firm performance first improves when total ownership concentration increases, and after a certain point (around $48 \%$ of total ownership concentration) firm performance decreases. For the effect of insider ownership concentration on firm performance the results were less convincing, but also statistically significant evidence was found.

In Africa, Ongore (2011) investigated the effects of ownership structure on the performance of listed companies in Kenya using agency theory as a theoretical framework. The study operationalized ownership structure using ownership concentration (percentage of shares owned by the top five shareholders) and ownership identity (actual identity of shareholders), and measure performance with return on assets, return on equity, and dividend yield. Using Pearson's product-moment correlation and logistic regression, Ongore (2011) found that ownership concentration and government ownership have significant negative relationships with firm performance and that foreign ownership, diffuse ownership, corporation ownership, and managerial ownership were found to have significant positive relationships with firm performance. 
In Nigeria, there are several studies on ownership structure and firm performance. But worthy of note due to their recent nature are those of Tsegba and Herbert (2013); Gugong et al. (2014); Andow and David (2016). The findings from these studies differ largely because of the different measures employed for both dependent and independent variables. Their methodologies also differ as well as the sectors studied.

Table 1. Summary of Selected Studies on Ownership Structures.

\begin{tabular}{|c|c|c|c|c|}
\hline Author(s) & $\begin{array}{l}\text { Dependent } \\
\text { variable(s) }\end{array}$ & $\begin{array}{c}\text { Independent } \\
\text { variables }\end{array}$ & $\begin{array}{l}\text { Method of } \\
\text { Analysis }\end{array}$ & Findings \\
\hline $\begin{array}{c}\text { Al-Matari \& Al- } \\
\text { Arusi (2016) }\end{array}$ & Return on Asset & $\begin{array}{l}\text { OWNCO, } \\
\text { MGOWN, } \\
\text { GOVOWN }\end{array}$ & $\begin{array}{l}\text { Multiple } \\
\text { regression }\end{array}$ & $\begin{array}{l}\text { + Significant } \\
\text { Insignificant } \\
+ \text { Significant }\end{array}$ \\
\hline Tahir et al. (2015) & $\begin{array}{c}\text { INOWN } \\
\text { Return on Asset }\end{array}$ & $\begin{array}{c}\text { Return on Asset } \\
\text { INOWN } \\
\text { Debt ratio }\end{array}$ & $\begin{array}{l}\text { OLS } \\
2 S L S\end{array}$ & $\begin{aligned} & \text { negative } \\
&+ \text { Significant } \\
& \text { negative } \\
&\end{aligned}$ \\
\hline Srivastava (2011) & $\begin{array}{c}\text { Return on Asset } \\
\text { Return on Equity } \\
\text { P/E } \\
\text { P/BV }\end{array}$ & $\begin{array}{l}\text { HIGHCON } \\
\text { DISPOWN }\end{array}$ & Regression & \\
\hline $\begin{array}{c}\text { Abeyrathna \& Ishari } \\
(2016)\end{array}$ & Return on Equity & $\begin{array}{l}\text { INOWN } \\
\text { BLOWN }\end{array}$ & Regression & $\begin{array}{l}\text { +Insignificant } \\
\text { - Insignificant }\end{array}$ \\
\hline $\begin{array}{c}\text { Alipour \& Amjadi } \\
\text { (2011) }\end{array}$ & Return on Asset & $\begin{array}{c}\text { BIGSH } \\
5 \% \text { BIGSH } \\
\text { INOWN } \\
\text { INDSH }\end{array}$ & Panel regression & $\begin{array}{l}\text { - Significant } \\
\text { +significant } \\
\text { - Significant } \\
\text { - Significant }\end{array}$ \\
\hline $\begin{array}{c}\text { Tsegba \& Herbert } \\
(2013)\end{array}$ & $\begin{array}{c}\text { Market Price } \\
\text { EPS }\end{array}$ & $\begin{array}{c}\text { OWNCO } \\
\text { FOWN }\end{array}$ & Panel regression & $\begin{array}{l}\text {-Significant } \\
+ \text { Significant }\end{array}$ \\
\hline $\begin{array}{c}\text { Manawaduge \& De } \\
\text { Zoysa (2013) }\end{array}$ & $\begin{array}{c}\text { Accounting \& } \\
\text { Market } \\
\text { Performance } \\
\end{array}$ & CONOWN & OLS & $\begin{array}{l}\text { +Significant } \\
\text { +Insignificant }\end{array}$ \\
\hline $\begin{array}{c}\text { Gurbuz \& American } \\
(2010)\end{array}$ & Return on Asset & $\begin{array}{l}\text { Min FOWN } \\
\text { Maj FOWN }\end{array}$ & Panel regression & Significant \\
\hline Gugong et al. (2014) & $\begin{array}{l}\text { Return on Asset } \\
\text { Return on Equity }\end{array}$ & $\begin{array}{l}\text { MGOWN } \\
\text { INOWN }\end{array}$ & Panel regression & + Significant \\
\hline $\begin{array}{l}\text { Andow \& David } \\
(2016)\end{array}$ & $\begin{array}{c}\text { financial } \\
\text { performance }\end{array}$ & FOWN & OLS & -Significant \\
\hline Ongore (2011) & $\begin{array}{l}\text { Return on Asset } \\
\text { Return on } \\
\text { EquityDividend } \\
\text { Yield }\end{array}$ & $\begin{array}{l}\text { OWNCO } \\
\text { GOVOWN } \\
\text { OWNID }\end{array}$ & $\begin{array}{c}\text { Correlation } \\
\text { Logit regression }\end{array}$ & $\begin{array}{l}\text {-Significant } \\
\text {-Significant } \\
+ \text { Significant }\end{array}$ \\
\hline
\end{tabular}

Note. Dependent and independent variables used in different studies on ownership structures and their findings. INOWN =Institutional ownership; $\mathrm{P} / \mathrm{E}=$ Price earnings ratio; $\mathrm{P} / \mathrm{BV}=$ Price to book value; $\mathrm{EPS}$ = Earnings per share; OWNCO =Ownership concentration; $\mathrm{MGOWN}=$ Managerial ownership; GOVOWN = Government ownership; HIGHCON= High concentration; DISPOWN = Dispersed ownership; BLOWN = Block ownership; BIGSH = Big shareholders; INDSH = Individual shareholders; FOWN = Foreign ownership; Min = Minority; Maj = Majority; OWNID = Ownership identity; OLS = Ordinary least square; 2 SLS $=$ Two stage least square.

Tsegba and Herbert (2013) used OLS to study 72 non-financial firms listed on the Nigerian Stock Exchange and found that while concentrated ownership has a significant negative impact on firm performance, foreign ownership has a significant positive impact on firm performance. Gugong et al. (2014) focused on both two aspects of ownership structure; managerial and institutional shareholding, and Firm's performance; Return on assets (ROA) and Return on Equity (ROE) for 17 listed insurance 
companies in Nigeria. Using panel regression, their findings indicated that there is a positive significant relationship between ownership structure and firm performance as measured by ROA and ROE. Andow and David (2016) assessed the impact of ownership structure on financial performance, using listed conglomerate firms in Nigeria. The study used regression to show that managerial and foreign ownership harms the performance of listed conglomerate firms.

Finally, looking at the researches reviewed in this study, one realizes that there are several measures for ownership structures as there are for firm performance. Most of the studies employed one form of regressions or the other in trying to model their study. Because of these, some had to write as many models as per their dependent variables which provides contradictory results. The study of these natures with multiple dependents and independents variables can best be modeled using multivariate techniques and that is what this study addresses.

\section{Data and Methods}

\subsection{Data and Variables}

Data for the study were collected from forty (40) non-financial firms listed on the NSE between 2011 and 2015 because the up-to-date information on most of these firms ends in 2015. Forty (40) of these firms were selected out of the sixty-seven (67) non-financial firms listed on the NSE, using the criteria that their;

1. Stocks must be traded actively during the study periods

2. Annual reports must be complete and up to date.

The study is restricted to non-financial firms because studies in this area in Nigeria are mostly on banks and other financial institutions.

Table 2. Description and Measurement of Variables

\begin{tabular}{ccc}
\hline Variables & Description & Measurement \\
\hline MGOWN & Percentage of share owned by managers of the firms & Ratio scale \\
\hline OWNCO & $\begin{array}{c}\text { the ratio of the stockholdings of the largest and the second } \\
\text { largest owner }\end{array}$ & Ratio scale \\
\hline FIOWC & percentage of shares held by each type of foreigners & Ratio scale \\
\hline INOWC & $\begin{array}{c}\text { Percentage of stocks held by investment firms, funds, and } \\
\text { other large entities }\end{array}$ & Ratio scale \\
\hline RETOA & The ratio of net income to total assets & Ratio scale \\
\hline RETOE & The ratio of net income to shareholders equity & Ratio scale \\
\hline TOBINQ & the market value of firms divided by its assets & Ratio scale \\
\hline EPS & company's net income divided by the total number of & Ratio scale \\
& outstanding shares. & \\
\hline
\end{tabular}

Note. The variables are computed as ratios. $\mathrm{MGOWN}=$ Managerial Ownership; $\mathrm{OWNCO}=$ Ownership Concentration; FIOWC; Foreign Institutional Ownership Concentration; INOWC $=$ Institutional Ownership Concentration; RETOE = Return on Equity; EPS = Earnings Per Share; RETOA = Return on Assets

The data were collected from the annual reports of these firms, which were accessible on the websites of NSE and the firms. The study employed eight variables; four as a measure for ownership structure and the other four as measures for firms' performance. The variables for ownership structure are managerial ownership (MGOWN), ownership concentration (OWNCO), foreign ownership concentration (FIOWC), and institutional ownership (INOWC) while the variables for firms' performance are Return on asset (RETOA), return on equity (RETOE), Tobin Q, and Earning Per Share (EPS). The descriptions and measurements for these variables are shown in Table 2. 


\subsection{Methods}

The method of data analysis for this study was canonical correlation because the data are multivariate, with four dependent variables. The Canonical Correlation is a multivariate analysis of correlation. It is the analysis of multiple- $X$ multiple- $Y$ correlation, which measures the strength of association between two Canonical Variates. For multiple $\mathrm{X}$ and $\mathrm{Y}$ the canonical correlation analysis constructs two variates:

$$
\begin{aligned}
& C V_{x 1}=a_{1} x_{1}+a_{2} x_{2}+a_{3} x_{3}+\ldots+a_{n} x_{n} \\
& C V_{y 1}=b_{1} y_{1}+b_{2} y_{2}+b_{3} y_{3}+\ldots+b_{m} x_{m}
\end{aligned}
$$

The canonical weights $a_{1} \ldots a_{n}$ and $b_{1} \ldots b_{n}$ are chosen so that they maximize the correlation between the canonical variates $C \mathrm{Vx}_{1}$ and $\mathrm{CV}_{\mathrm{Y} 1}$.

The two-column vectors $\mathrm{X}$ and $\mathrm{Y}$ are given as;

$$
\begin{gathered}
X=(\text { MGOWN }, \text { OWNCO, FIOWC, INOWC }) \\
Y=(\text { TOBIN } Q, \text { RETOA, RETOE, EPS })
\end{gathered}
$$

The cross variance $\sum X Y=\operatorname{Cov}(\mathrm{X}, \mathrm{Y})$ is an $n \times m$ matrix whose $(i, j)$ entry is the covariance $\operatorname{cov}\left(\mathrm{x}_{\mathrm{i}}\right.$, $\mathrm{y}_{\mathrm{i}}$ ). The model seeks vectors $\boldsymbol{a}\left(\boldsymbol{a} \in \boldsymbol{R}^{n}\right)$ and $\boldsymbol{b}\left(\boldsymbol{b} \in \boldsymbol{R}^{m}\right)$ such that the random variable $a^{T} X$ and $b^{T} Y$ maximize the correlation $p=\operatorname{corr}\left(a^{T} X, b^{T} Y\right)$. The random variables $U=a^{T} X$ and $V=b^{T} Y$ are the first pair of canonical variables. Then one seeks vectors maximizing the same correlation subject to the constraint that they are to be uncorrelated with the first pair of canonical variables; this gives the second pair of canonical variables. This procedure may be continued up to $\min \{m, n\}$ times.

Specifically, the Canonical correlation model for this study is expressed in equation (3) and (4) as the relationship is depicted in Figure 1.

$$
\begin{gathered}
C V_{x 1}=\alpha_{1} \text { MGOWN }+\alpha_{2} \mathrm{OWNCO}+\alpha_{3} \text { FIOWC }+\alpha_{4} \text { INOWC } \\
C V_{y 1}=\beta_{1} \text { TOBINQ }+\beta_{2} \text { RETOA }+\beta_{3} \text { RETOE }+\beta_{4} \text { EPS }
\end{gathered}
$$

Figure 1. Canonical Correlation Model

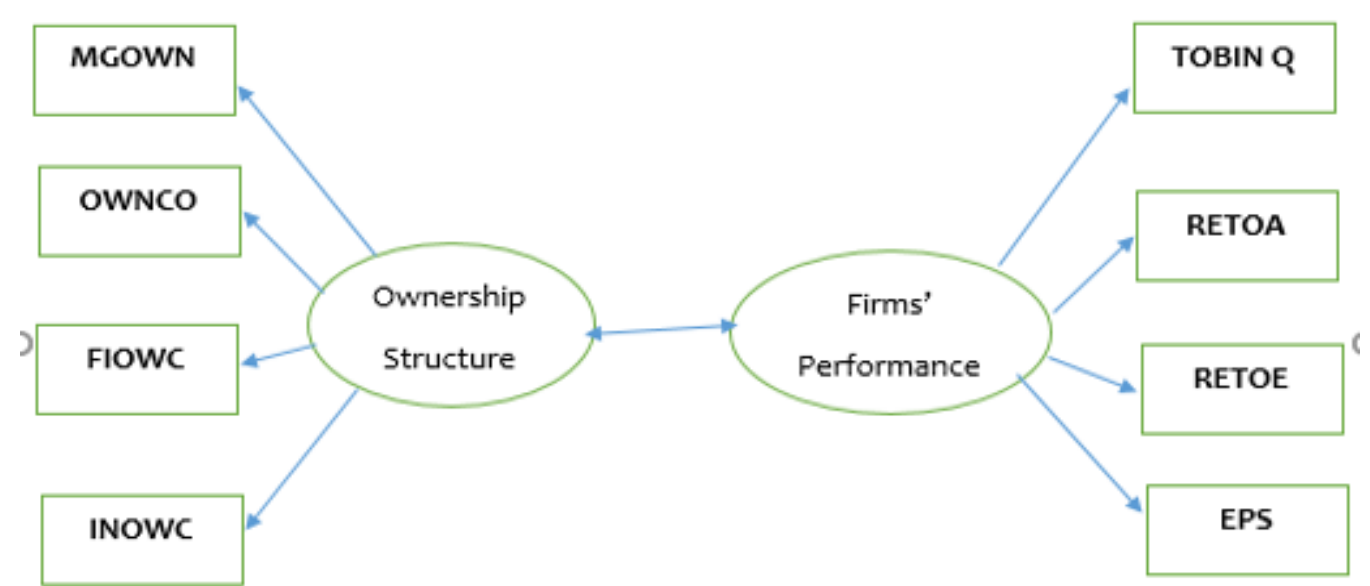

Note. The ownership structure has four proxies. Firms' performance has four proxies. MGOWN = Managerial Ownership; OWNCO = Ownership Concentration; FIOWC; Foreign Institutional Ownership Concentration; INOWC = Institutional Ownership Concentration; RETOE = Return on Equity; EPS = Earnings Per Share; RETOA = Return on Assets

\section{Results and Discussion}

Table 2 shows the descriptive statistics for all the variables used in this study. The average value for TOBIN Q, RETOE, EPS, and RETOA are 1.953, 19.667, 2.180, and 6.370 respectively. The minimum 
and maximum value of the performance variables shows the presence of outliers as there is a larger difference between these values for all variables. This is because some of the firms in the panel data set reported some abnormally high or low-performance indicators.

For the ownership structure measures, the average values are 13.503, 57.240, 24.541,51.312,1.953,19.667,2.180, and 6.370 for MGOWN, OWNCO, FIOWC, INOWC, TOBINQ, RETOE, EPS, and RETOA respectively. The minimum and maximum value of these variables also show the presence of outliers as there some of the ownership structure for some of the firms were zeros. This result in a larger difference between these values for all variables

Table 3. Summary Statistics of the variable

\begin{tabular}{ccccccccc}
\hline STATS & TOBINQ & RETOE & EPS & RETOA & MGOWN & OWNCO & FIOWC & INOWC \\
\hline Mean & 1.953 & 19.667 & 2.180 & 6.370 & 13.503 & 57.240 & 24.541 & 51.312 \\
p50 & 1.355 & 13.18 & 0.755 & 5.66 & 0.965 & 60 & 0 & 57 \\
Sd & 1.668 & 54.829 & 4.865 & 10.981 & 22.418 & 19.269 & 29.559 & 25.561 \\
Min & 0.39 & -112.45 & -2.51 & -25.69 & 0 & 0 & 0 & 0 \\
Max & 10.83 & 520.52 & 32.53 & 53.96 & 84.44 & 91 & 82 & 91 \\
N & 200 & 200 & 200 & 200 & 200 & 200 & 200 & 200 \\
\hline
\end{tabular}

Note. The values are in percentages. STATS = Statistic; RETOE = Return on Equity; EPS = Earnings Per Share; RETOA = Return on Assets; MGOWN = Managerial Ownership; OWNCO = Ownership Concentration; FIOWC; Foreign Ownership Concentration; INOWC = Institutional Ownership Concentration; p50 = Median; Sd = Standard deviation; Min = Minimum value; Max = Maximum value

Table 4 shows the correlation analysis exhibited by the performance variables. It shows positive relationships among all of them. None of the correlation value shows a strong value, meaning that there is no Multicollinearity among the variables.

Table 4. Correlation Matrix of the Performance Variables

\begin{tabular}{ccccc}
\hline & TOBINQ & RETOE & EPS & RETOA \\
\hline TOBINQ & 1.0000 & & & \\
RETOE & 0.2790 & 1.0000 & & \\
EPS & 0.5495 & 0.1539 & 1.0000 & 1.0000 \\
RETOA & 0.6178 & 0.2669 & 0.4262 & \\
\hline
\end{tabular}

Note. The correlation coefficient of dependent variables to check multicollinearity. RETOE = Return on Equity; EPS = Earnings Per Share; RETOA = Return on Assets

Table 5 shows the correlation analysis exhibited by the ownership structure variables. Some exhibited negative relationships and others show positive relationships between them. The correlation values are not strong except that of OWNCO and INOWC.

Table 5. Correlation Matrix of the Ownership Structures Variables

\begin{tabular}{ccccc}
\hline & MGOWN & OWNCO & FIOWC & INOWC \\
\hline MGOWN & 1.0000 & & & \\
OWNCO & -0.1418 & 1.0000 & & \\
FIOWC & -0.4660 & 0.2715 & 1.0000 & 1.0000 \\
INOWC & -0.3321 & 0.8636 & 0.3902 & \\
\hline
\end{tabular}

Note. The correlation coefficient of independent variables to check multicollinearity. MGOWN = Managerial Ownership; OWNCO = Ownership Concentration; FIOWC; Foreign Institutional Ownership Concentration; INOWC = Institutional Ownership Concentration 
A canonical correlation analysis was conducted using the four variables of ownership structure as predictors of the 4 firms' performance variables to evaluate the multivariate shared relationship between the two variable sets (ownership structure and firms' performance). The analysis yielded four functions with canonical correlation coefficients $\left(R_{c}\right)$ of $0.4392,0.2658,0.0884$, and 0.0259 . The squared canonical correlations $\left(\mathrm{R}^{2}\right)$ of $0.1929,0.0706,0.0078$, and 0.00067 for each successive function. This shows that the ownership structure has a positive correlation with the performance measures. This finding is consistent with the studies of Alfarooque et al. (2020); Al-Matari and Al-Arusi (2016), Gugong et al. (2014); Kao et al. (2018); Manawaduge and De Zoysa (2013); Mardnlt et al. (2018); Rashid (2020) with similar findings. Other studies like Ali (2018); Alipor and Amjadi (2011), Andow and David (2016), Ongore (2011), and Tahir et al. (2015) reported a negative correlation, which made their results inconsistent with that of this study.

Table 6. Correlation Coefficients

\begin{tabular}{|c|c|c|c|c|c|c|}
\hline 0.4392 & \multicolumn{2}{|l|}{0.2658} & \multicolumn{2}{|l|}{0.0884} & \multicolumn{2}{|c|}{0.0259} \\
\hline \multicolumn{7}{|c|}{$\begin{array}{l}\text { Note. The canonical correlation coefficient of the four functions. Functions } 1 \text { and } 2 \text { give higher values. } \\
\text { Collectively, the full model across all functions was statistically significant using the Wilks' } \\
0.7438 \text { criterion, } F(16,587.21)=3.7344, p=0.000 \text {. Because Wilks's } \lambda \text { represents the variance unexpla } \\
\text { by the model, } 1-\lambda \text { yields the full model effect size in an } r^{2} \text { metric. Thus, for the set of four cano } \\
\text { functions, the } r^{2} \text { type effect size was } .2562 \text {, which indicates that the full model explained a substa }\end{array}$} \\
\hline \multicolumn{7}{|c|}{ Table 7. Test of Significance of all Canonical Correlations } \\
\hline Tests & Statistic & df1 & df2 & $\mathbf{F}$ & Prob $>F$ & \\
\hline Wilks' lambda & 0.7438 & 16 & 587.207 & 3.7344 & 0.000 & A \\
\hline Pillai's trace & 0.2720 & 16 & 780 & 3.5567 & 0.000 & A \\
\hline Lawley-Hotelling trace & 0.3235 & 16 & 762 & 3.8518 & 0.000 & A \\
\hline Roy's largest root & 0.2390 & 4 & 195 & 11.6498 & 0.000 & $\mathrm{U}$ \\
\hline
\end{tabular}

Note. The models are significant at $p=5 \%$, as indicated by the four different tests

The dimension reduction analysis allows us to test the hierarchal arrangement of functions for statistical significance. As noted, the full model (Functions 1 to 4) was statistically significant. Functions 2 to 4 was also statistically significant at 10\%, 3 to 4 and 4 did not explain a statistically significant amount of shared variance between the variable sets, $F(4,388)=0.4138, p=0.4138$, and $F(1$, 195) $=0.1313, p=0.7175$, respectively.

Given the effects for each function, only the first two functions were considered noteworthy in the context of this study (19\% and $7 \%$ of the shared variance, respectively), and thus, was interpreted The last two functions only explained $0.78 \%$ and $0.067 \%$, respectively, of the remaining variance in the variable sets after the extraction of the prior functions.

Table 8 presents the standardized canonical function coefficients and loadings coefficients for Functions 1 and 2. The squared loadings coefficients are also given as well as the commonalities $\left(h^{2}\right)$ across the two functions for each variable. Looking at the Function 1 coefficients, one sees that relevant criterion variables were primarily foreign ownership concentration and managerial ownership. This conclusion was supported by the squared structure (loading) coefficients. These ownership structures also tended to have larger canonical function coefficients. This is in line with the study of Alfarooque (2020); Gurbuz and American (2010), Kao et al. (2020); Mardnly et al (2018); Rashid (2020); Tsegba and Herbert (2013), but Ali et al. (2020); Al-Matari and Al-Arusi (2016) reported differently.

Furthermore, except for managerial ownership, all of these variables' structure coefficients had the same sign, indicating that they were all positively related. Managerial ownership was inversely related to the other performance measures, which is inconsistent with the findings of Ali et al. (2020); Al-Matari and Al-Arusi (2016). 
Table 8. Canonical Solution for Ownership Structure Predicting Firms' Performance

\begin{tabular}{cccccccc}
\hline \multicolumn{7}{c}{ function 1 } \\
\hline Variable & std. coeff & loadings $\left(\mathrm{r}_{\mathrm{s}}\right)$ & $\mathrm{rs}^{2}(\%)$ & std. coeff & loadings $\left(\mathrm{r}_{\mathrm{s}}\right)$ & $\mathrm{rs}^{2}(\%)$ & $\mathrm{h}^{2}(\%)$ \\
MGOWN & -0.2896 & $\underline{-0.6900}$ & 47.61 & -0.7171 & $\underline{-0.5900}$ & 34.81 & $\underline{82.42}$ \\
OWNCO & -0.4739 & 0.0312 & 0.10 & -0.5472 & 0.2165 & 4.69 & 4.78 \\
FIOWC & 0.7996 & $\underline{0.9174}$ & 84.16 & -0.8407 & -0.2529 & 6.40 & $\underline{90.56}$ \\
INOWC & 0.2858 & 0.2848 & 8.11 & 1.0308 & $\underline{0.4683}$ & 21.93 & 30.04 \\
TOBINQ & 0.8295 & $\underline{0.6235}$ & 38.88 & 0.5944 & $\underline{0.7801}$ & 60.86 & $\underline{99.73}$ \\
RETOE & 0.0751 & 0.1606 & 2.58 & 0.0094 & 0.2921 & 8.53 & 11.11 \\
EPS & 0.5736 & $\underline{0.6670}$ & 44.49 & -0.4527 & 0.1732 & 3.00 & $\underline{47.49}$ \\
RETOA & -0.8774 & -0.1005 & 1.01 & 0.6988 & $\underline{0.8757}$ & 76.69 & $\underline{77.70}$ \\
\hline
\end{tabular}

Note. The standard coefficient shows the direction of relationships. The loadings and the squared loadings show which criterion variable(s) is relevant. The communalities $\left(h^{2}\right)$ is the sum of squared factor loadings for the variables. MGOWN = Managerial Ownership; OWNCO = Ownership Concentration; FIOWC; Foreign Ownership Concentration; INOWC = Institutional Ownership Concentration; RETOE = Return on Equity; EPS = Earnings Per Share; RETOA = Return on Assets.

Regarding the predictor variable set in Function 1, earning per share and Tobin q variables were the primary contributors to the predictor synthetic variable. Because the structure coefficient for all the primary contributors was positive, they are positively related to all of the ownership structure variables.

Moving to Function 2, the coefficients in Table 8 suggest that the only criterion variables of relevance were managerial ownership and institutional ownership concentration. While managerial ownership is positively related as found by Alabdullah (2018); Al-Matari and Al-Arusi (2016); Rashid (2020), institutional ownership concentration was inversely related on this function (Ali et al., 2018), which is not consistent with the study of Abeyrathna \& Ishari (2016). As for performance measures, Tobin $q$ and return on assets were the dominant predictors, and these performance variables were also inversely related.

\section{Conclusions}

This study examined the relationship between ownership structure and performance of listed non-financial firms in Nigeria using the canonical correlation to estimate the overall relationship. From the findings, it can be concluded that the dominant ownership structure variables in the relationship are managerial and foreign ownership, while the dominants performance variables are the Tobin $q$, earning per share, and return on asset. The ownership structure variables are all positively correlated with a firm performance for listed non-financial firms in Nigeria. It is recommended that non-financial firms should encourage managerial ownership in the form of rewarding managers with shares in the firm. They should also encourage foreign ownership in the firm as this will boost investors' confidence.

The limitations of this study are the restrictions of the dependent and independent variables to only four each and the inability to access the data of all the listed non-financial firms on the NSE. Although, the data of the firms collected are the dominant and consistent players in the industry. They trade on the floor of the NSE frequently and publish their annual reports consistently. This makes the result of the study credible and generalizable. Thus, subsequent studies can extend the study using other ownership structure and performance variables not considered in this study.

Author Contributions: The individual contributions of the authors are stated below. Conceptualization: Dr. Abdul Adamu and Dr. Joel Haruna Formal analysis: Dr. Abdul Adamu. Methodology: Dr. Abdul Adam. Validation: Dr. Abdul Adamu and Dr. Joel Haruna. Investigation: Dr. Abdul Adamu and Dr. Joel Haruna. Resources: Dr. Abdul Adamu. Data curation: Dr. Joel Haruna. Writing-original draft preparation: Dr. Abdul Adamu. Writing - review, and editing: Dr. Abdul Adamu and Dr. Joel Haruna. Visualization: Dr. Abdul Adamu. 
Supervision: Dr. Abdul Adamu and Dr. Joel Haruna. Project administration: Dr. Abdul Adamu and Dr. Joel Haruna. Visualization: Dr. Abdul Adamu.

Funding: This research received no external funding.

Acknowledgments: We thank Dr. Zainab Abdul Husseini for her remarks, which helped to improve this work.

Conflicts of Interest: The authors declare no conflict of interest.

\section{References}

Abeyrathna, G.M. \& Ishari, S. (2016). Impact of ownership structure on firms' performance of manufacturing companies in Sri Lanka. International Journal of Scientific and Research, 6(10), 111-115.

Alabdullah, T.T.Y. (2018) "The relationship between ownership structure and firm financial performance: Evidence from Jordan", Benchmarking: An International Journal, 25(1), 319-333, https://doi.org/10.1108/BIJ-042016-0051

Ali, A., Qiang, F. \& Ashraf, S. (2018), "Regional dynamics of ownership structure and their impact on firm performance and firm valuation: A case of Chinese listed companies", Review of International Business and Strategy, 28 (1), 129-147. https://doi.org/10.1108/RIBS-02-2017-0017

Alipour, M. \& Amjadi, H. (2011). The effect of ownership structure on corporate performance of listed companies in Tehran stock exchange: An empirical evidence of Iran. International Journal of Business and Social Science 2(13), 49-55.

Al Farooque, O., Buachoom, W. \& Sun, L. (2020). Board, audit committee, ownership, and financial performance emerging trends from Thailand. Pacific Accounting Review, 32 (1), 54-81. https://doi.org/10.1108/PAR-10-2018$\underline{0079}$

Al-Matari, E.M. \& Alarussi, A.S. (2016). The effect of the ownership structure characteristics on firm performance in Oman: Empirical study. Corporate ownership and control Journal 13(2), pg. $93 \quad-\quad 100$. https://doi.org/10.22495/cocv13i2p10

Andow, H.A. \& David, B.M. (2016). Ownership structure and the financial performance of listed conglomerate firms in Nigeria. The business and management review, 7(3), 231-240

Arosa, B., Iturralde, T., \& Maseda, A. (2009). Ownership Structure and Firm Performance in Non-Listed Firms: Evidence from Spain. World Family Business Research Conference of IFERA, University of the Basque Country, UPV/EHU, Spain

Berle, A. \& Means, G. (1932) The modern corporation and private property. Commerce Clearing House, New York.

Demsetz, H. \& Lehn, K. (1985). The structure of corporate ownership: Causes and consequences. Journal of Political Economy, 93 (6), 1155-1177.

Demsetz, H. \& Villalonga, B. (2001). Ownership structure and corporate performance. Journal of Corporate Finance 7, 209-233

Gugong, B.K., Arugo, L.O. \& Dandago, K.I. (2014). The impact of ownership structure on the financial performance of listed insurance firms in Nigeria. International journal of academic research in accounting, finance and management sciences, 4(1), 409-416.

Gurbuz, A.O. \& American, A.A. (2010). The impact of foreign ownership on firm performance, evidence from an emerging market: Turkey. Journal of economics and business administration 2 (4): 350-359

Jadoon, I.A. \& Bajuri, N.H. (2015). Ownership concentration and firm performance: Evidence from Pakistan. European journal of business and management 7(17), $200-207$.

Jensen, M.C. \& Meckling, W.H. (1976). Theory of the firm: Managerial behavior, agency costs, and ownership structure. Journal of Financial Economics 3(4), 305-360.

Kao, M., Hodgkinson, L. \& Jaafar, A. (2018). Ownership structure, the board of directors, and firm performance: evidence from Taiwan. Corporate Governance, 19 (1), 189-216.

Lauterbach, B. \& Vaninsky, A. (1999). Ownership structure and firm performance: Evidence from Israel. Journal of Management and Governance 3: 189-201.

Manawaduge, A. \& De Zoysa, A. (2013). The structure of corporate ownership and firm performance: Sri Lankan evidence. Corporate Ownership \& Control, 11(1), 723-734.

Mardnly, Z., Mouselli, S, \& Abdulraouf, R. (2018). Corporate governance and firm performance: empirical evidence from Syria. International Journal of Islamic and Middle Eastern Finance and Management, Vol. 11 Issue: 4, pp.591-607, https://doi.org/10.1108/IMEFM-05-2017-0107

Ongore, V.O. (2011). The Relationship between Ownership Structure and Firm Performance: An Empirical Analysis of Listed Companies in Kenya. African Journal of Business Management 5(6), 2120-2128. 
Rashid, M.M. (2020), Ownership structure, and firm performance: the mediating role of board characteristics, Corporate Governance, 20 (4), 719-737. https://doi.org/10.1108/CG-02-2019-0056

Scholten, M. (2014). Ownership structure and firm performance: Evidence from the Netherlands. $1^{\text {st }}$ IBA Bachelor Thesis Conference, Enschede, The Netherland. The University of Twente, Faculty of Management and Governance.

Srivastava, A. (2011). Ownership structure and corporate performance: Evidence from India. International Journal of Humanities and Social Science 1(1), 23 - 29.

Tahir, H. S., Saleem, M. \& Arshad, H. (2015). Institutional ownership and corporate value: Evidence from Karachi Stock Exchange (KSE) 30-Index Pakistan. Praktični menadžment, 5 (1), 41-49.

Tsegba, I.N. \& Herbert, W.E. (2013). Corporate governance, ownership structure, and firm performance in Nigeria. Research Journal of Finance and Accounting 4(5), 23 - 38.

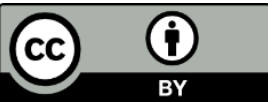

(c) 2020 by the authors. This article is an open-access article distributed under the terms and conditions of the Creative Commons Attribution (CC BY) license (http://creativecommons.org/licenses/by/4.0/). 